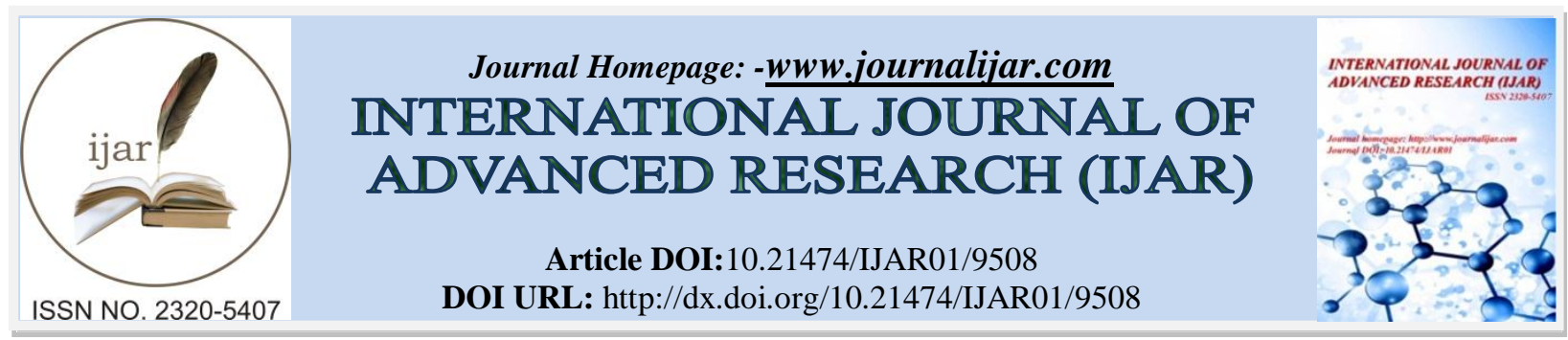

RESEARCH ARTICLE

\title{
A MISLEADING SITE OF BASAL CELL CARCINOMA.
}

\section{Hicham Sabani $^{1}$ and Karim EL Khatib ${ }^{2}$.}

1. Assistant Professor, Department of Plastic and Maxillofacial Surgery, Mohammed V Military Hospital, Hassan II University, Casablanca, Morocco.

2. Professor, Department of Plastic and Maxillofacial Surgery, Mohammed V Military Hospital, Mohammed V University, Rabat, Morocco.

\section{Manuscript Info}

\section{Manuscript History}

Received: 06 June 2019

Final Accepted: 08 July 2019

Published: August 2019

Key words:-

Basal cell carcinoma, Lip mucosa,

Vermilion, Mohs surgery.

\begin{abstract}
Basal cell carcinoma (BCC) is an extremely common malignant tumor of the skin arising from basal cells of the lower epidermis and adnexal structures, that usually occurs on the head or neck. However very rare cases of BCC arising from vermilion mucosa of lip have been reported in the literature, and The exact pathogenesis of vermilion lip BCC is not clear.

Here, we report a rare case of a 35-year-old woman with BCC evolving for 5 years and having interested the vermilion mucosa of the lower lip. The diagnosis of BCC was confirmed with histopathological examination. The Tumor was excised with surrounding normal tissue margins and the reconstruction was done by a flap.

We believe that the histopathological examination is the only guarantee that allows to recognize a $\mathrm{BCC}$ of the vermilion lip which is the usual site of the squamous cell carcinoma, and thus to avoid to the patient a very aggressive surgery with ganglionic dissection.
\end{abstract}

Copy Right, IJAR, 2019,. All rights reserved.

\section{Introduction:-}

Basal-cell carcinoma (BCC) is the most common type of skin cancer (1).It touches in more than $80 \%$ of patients case the cephalic extremity, particularly the two-thirds upper facial (2). Unlike squamous cell carcinoma (SCC), it affects only rarely the labial mucosa $(3,4)$ and preferentially reaches the upper lip (3). In fact, There are few reports in the literature of BCC on the vermilion area. Here, we report an interesting case of BCC developed on the lower vermilion mucosa that had initially been treated with conventional therapies.

\section{Case Report :}

A 35-year-old woman consulted for a lesion of the lower lip, which dates back 5 years, started in vermillion and gradually progressed in a retractile mode and asymptomatic context, without pain or bleeding. This lesion was treated as a simple skin rash but without improvement.

The interrogation did not find any notion of trauma old or alcoholic or smoking intoxication. The physical examination revealed an infiltrating and retractile lesion of $2 \mathrm{~cm}$ in diameter, crusting and bleeding easily in the conatct, sitting on the inferior vermilion and overlying the cutaneous side and internal mucosa (fig.1,2). The oral mucosa was also free of any pre-epitheliomatous lesions. He did not exist palpable cervical lymphadenopathy.

Corresponding Author:-Hicham Sabani.

Address:-Assistant Professor, Department of Plastic and Maxillofacial Surgery, Mohammed V 
The diagnosis of BCC was confirmed with histopathological examination (fig. 3) after biopsy of the mucosal neoplasm. We performed surgical treatment with $10 \mathrm{~mm}$ margin and reconstruction with Estlander'sheterolabial flap (fig.4,5). After surgery, no recurrency was seen after 12 months follow-up the patient.

\section{Discussion:-}

Lip is a relatively unique because it is a junctional structure. In fact The lip is bounded externally by the facial skin and is continuous with the buccal mucosa in the oral cavity.

The vermillion is a transition layer between the outer, hair-bearing tissue and the inner mucous membrane.

The vermilion of the lips is comprised of a modified mucous membrane composed of hairless, highly vascularized, nonkeratinized stratified squamous epithelium. Additionally, the vermilion lacks the typical skin appendages seen in the cutaneous lip, bearing no hair follicles or salivary, sweat and sebaceous glands (5).

The distribution of malignant tumors of the lips is usually divided between SCC of the lower lip and BCC of the upper lip (3). BCC is more commonly encountered on the cutaneous lip, whereas SCC is more common on the vermilion lip.

$\mathrm{BCC}$ of the vermilion lip is very rare.

Our case draws attention to this rare site of $\mathrm{BCC}$ since the tumor was initially located on the lower vermilion lip. It has been reported a limited number of BCC involving primarily the vermilion border or outer mucosal surface of lip. In 1949, study of 620 cases of BCC at all sites indicated that there were 2 cases of BCC on the lower lip mucosa (6). In 1975, a retrospective review of 652 cases of BCC by Weitzner et al.(7) indicated that there were 3 cases of BCC on the vermilion mucosa.The largest serie described in the literature is silapunt in 2004, which reported only 18 cases of BCC on the vermilion lip from 7027 cases of histopathologically confirmed BCC.

To date, there is no unanimous explanation about The precise histogenesis of BCC on the vermilion lip. Some authors have suggested that it could derive from pluripotential epithelial cells of the oral mucosa and epidermis, however the other authors consider their origin from ectopic sebaceous glands (8). The other possibility of origin may be from traumatic epithelial implantation (3).

Excisional biopsy with histopathology is the gold standard for diagnosis. No suspected lesion should be treated without histopathologic confirmation.

All histological types of basal cell carcinoma can be observed: superficial, infiltrating, nodular and sclerodermiform. $(2,3)$ The infiltrating form, found in our patient, being the one most often described (2). Invasion of deep structures is usually early because of the proximity of the orbicularis muscle of the lip.

The purpose of treatment of BCC is to completely remove the tumor and maximally preserve function and cosmesis at the site of the lesion. Preservation of function and cosmesis is essential in certain locations, such as the face. A variety of surgical and medical therapies are available for the treatment of BCC.

Choice of treatment depends in large part on the risk of lesion recurrence, which in turn depends on the presence or absence of aggressive clinical and histopathologic features (9).

Surgical excision is the gold standard for treatment (10). Mohs micrographic surgery (MMS) is a specialized method for the removal of skin cancer that combines surgery with pathology (11). It has an evidence-based, 5-year cure rate of $99 \%$ for basal cell carcinoma (BCC) $(12,13)$.

Mohs surgery is indicated for lesions at increased risk of recurrence and where functional and anatomic relations need to be preserved. this technique is the preferred treatment for BCC at high risk for recurrence $(9,14,15)$.

Radiation therapy is a good alternative for patients who are not surgical candidates or who refuse surgery (10).

Topical medications such as 5-fluorouracil or imiquimod may be used for superficial basal cell carcinoma in lowrisk patients who are unable or unwilling to undergo surgery or radiation therapy (10). 
Systemic medications such as hedgehog pathway inhibitors (vismodegib and sonidegib) may be used when basal cell carcinoma is advanced (16).

\section{Conflicts of Interest :}

The authors declare that they have no conflicts of interest concerning this article.

\section{Acknowledgements:-}

The authors are grateful for a cytopathologist Youssef BOUHAJEB who provided a histopatholgical analysis and images.

\section{References:-}

1. Marzuka AG, Book SE. Basal cell carcinoma: pathogenesis, epi-demiology, clinical features, diagnosis, histopathology, and man-agement. Yale J Biol Med2015;88:167-79.

2. Huynh NT, Veness MJ. Basal cell carcinoma of the lip treated with radiotherapy. Australas J Dermatol 2002;43:15-9.

3. Silapunt S, Peterson SR, Goldberg LH, Friedman PM, Alam M. Basal cell carcinoma on the vermilion lip: a study of 18 cases. J Am Acad Dermatol 2004;50:384-7.

4. Fitzpatrick PJ. Cancer of the lip. J Otolaryngol 1984;13:32-6.

5. Piccinin MA, Zito PM. Anatomy, Head and Neck, Lips. In : StatPearls [Internet]. Treasure Island (FL): StatPearls Publishing; 2019 Feb 8.

6. Welton DG, Elliott JA, Kimmelstiel P. Epithelioma: clinical and histologic data on 1025 lesions. Arch Dermatol. 1949;60:277-933.

7. Weitzner S. Basal cell carcinoma of the vermillion mucosa and skin of the lip. Oral Surg Oral Med Oral Pathol. 1975;39:634-7.

8. Luna-Ortiz K, Güemes-Meza A, Villavicencio- Valencia V, Mosqueda-Taylor A. Upper lip malignant neoplasms. A study of 59 cases. Med Oral Patol Oral Cir Bucal. 2012;17(3):e371-e376.

9. Miller SJ, Alam M, Andersen J, Berg D, Bichakjian CK, Bowen G, et al. Basal cell and squamous cell skin cancers. J Natl Compr Canc Netw. 2010;8(8):836-64.

10. NCCN: Basal Cell Skin Cancer. NCCN website. Version I.2017. Published October 3, 2016. Accessed May 8, 2017. https://www.nccn.org/professionals/physician_gls/pdf/nmsc.pdf

11. Mohs Micrographic Surgery Charlene Lam and Allison T. Vidimos.

12. Rowe DE, Carroll RJ, Day CL Jr. Long-term recurrence rates in previously untreated (primary) basal cell carcinoma: implications for patient follow-up. J Dermatol Surg Oncol 1989;15:315-28.

13. 13-Rowe DE, Carroll RJ, Day CL. Mohs surgery is the treatment of choice for recurrent (previously treated) basal cell carcinoma. J Dermatol Surg Oncol 1989;15:424-31.

14. Drake LA, Dinehart SM, Goltz Rw, Graham GF, Hordinsky MK, Lewis Cw, et al. Guidelines of care for Mohs micrographic surgery. American Academy of Dermatology. J Am Acad Dermatol. 1995;33(2 Pt 1):271-8.

15. Ad Hoc Task Force, Connolly SM, Baker DR, Coldiron BM, Fazio MJ, Storrs PA, et al. AAD/ACMS/ASDSA/ASMS 2012 appropriate use criteria for Mohs micrographic surgery: a report of the American Academy of Dermatology, American College of Mohs Surgery, American Society for Dermatologic Surgery Association, and the American Society for Mohs Surgery. J Am Acad Dermatol. 2012;67(4):531-50.

16. Bichakjian CK et al: Basal Cell Skin Cancer, Version 1.2017, NCCN Clinical Practice Guidelines in Oncology. October 3, 2016. 